\title{
Review on Ethnomedicinal uses of Memory Boosting Herb, Butterfly Pea, Clitoria ternatea
}

\author{
Piya Kosai, Kanjana Sirisidthi, Kanitta Jiraungkoorskul and \\ Wannee Jiraungkoorskul*
}

\author{
Department of Pathobiology, Faculty of Science, Mahidol University, Bangkok - 10400, Thailand
}

\begin{abstract}
Clitoria ternatea (Family: Fabaceae) is one of the traditional medicinal plants used as "Shanka Pushpi" an Ayurvedic medicine used to boost or enhance neurological health. The plant contains alkaloid, flavonoid, taraxerol, taraxerone, triterpenoid and anthocyanin as active chemicals that bring about its biological effects. Its extracts possess a wide range of pharmacological activities including antibacterial, anti-diabetic, anti-diarrheal, anti-fungal, anti-helmintic, antiinflammatory, antimicrobial, antioxidant, and antipyretic activities, hypolipidemia, immunomodulatory, and wound healing. This review is an attempt to compile information on various ethnomedicinal uses of memory boosting herb, butterfly pea, Clitoria ternatea. Conclusion: It has a wide spectrum of neuropharmacological benefits such as nootropic, anti-depressant, anti-stress, anxiolytic, and anticonvulsant activities.
\end{abstract}

Keywords: Butterfly Pea, Clitoria ternatea, Herb, Memory, Neuropharmacology, Plant

\section{Introduction}

Alzheimer's disease is a multifactorial neurodegenerative disorder affecting multiple clinical domains involving cognitive functioning, behavioral aspects, and functionalphysical skills, the causes and the progression are still not well-understood ${ }^{1}$. National estimates, one-third or $32 \%$ of people age 85 and older in the United States has Alzheimer's disease ${ }^{2}$. Charern boon and Phanasathit ${ }^{3}$ evaluated the 62 patients who were diagnosed as having Alzheimer's disease, according to the National Institute of Neurological and Communicative Disorders and Stroke and Alzheimer's Disease and Related Disorders Association (NINCDS-ADRDA) criteria and received global Clinical Dementia Rating scale score of at least stage one. They used the Neuropsychiatric Inventory Questionnaire and the Thai Mental State Examination, the most common symptoms were apathetic, aberrant motor behavior, sleep and eating problems, agitation, aggression, euphoria and memory complaints. The pathological features that have been identified in the central nervous system in Alzheimer's disease are senile plaques and neurofibrillary tangles, oxidative and inflammatory processes, neurotransmitter disturbances, and cholinergic deficit. Thus, attempts to restore these features have been a rational target for drugs used to treat the symptoms of Alzheimer's disease. Approaches to enhance cholinergic function have included stimulation of cholinergic receptors or prolonging the availability of acetylcholine released into the neuronal synaptic cleft by inhibiting the acetylcholine hydrolysis by acetylcholinesterase ${ }^{4}$. Currently available treatment i.e., acetylcholinesterase inhibitors (rivastigmine, galantamine, and donepezil) and $\mathrm{N}$-methyl-d-aspartate

\footnotetext{
${ }^{*}$ Author for correspondence

Email: pathobiologymu@gmail.com
} 
receptor antagonist (memantine) contribute minimal impact on the disease and target late aspects of the disease. These drugs decelerate the progression of the disease, provide symptomatic relief, but fail to achieve a definite cure ${ }^{5}$. Traditional practices of medicine, plants have been used to enhance cognitive function and to alleviate other symptoms associated with Alzheimer's disease $^{6-8}$.

\section{Nomenclature}

There are around 60 global species belonging to genus Clitoria, which originated from the tropical equatorial Asia, and later was distributed widely in South and Central America, East and West Indies, Africa, Australia9. The vernacular name of Clitoria ternatea is also known as butterfly pea, blue pea, (English), aparajita (Bengali), cunha (Brazilian), lan hu die, lan hua dou (Chinese), aparajit (Hindi), kajroti (India), bunga biru, tembang telang (Indonesian), bunga biru, kacang telang (Khmer), ang san dam, bang san dam (Lao), bunga telang (Malaysian), cunhã, fula criqua (Portuguese), aparajita (Sanskrit), clitoria azul, azulejo, conchitis, bejuco de conchitas (Spanish), kakkattan, sangupushpam (Tamil), nalla ghentana (Telugu), un-chan, uang-chan, dangchan (Thai), mavi kelebek sarmaşığ 1 (Turkish), and chi dậu biếc (Vietnamese) $)^{10,11}$.

\section{Morphological Characters}

Clitoria ternatea (Figure 1.) is an ornamental perennial climber, twining fine stems, up to $2-3 \mathrm{~m}$ in height,
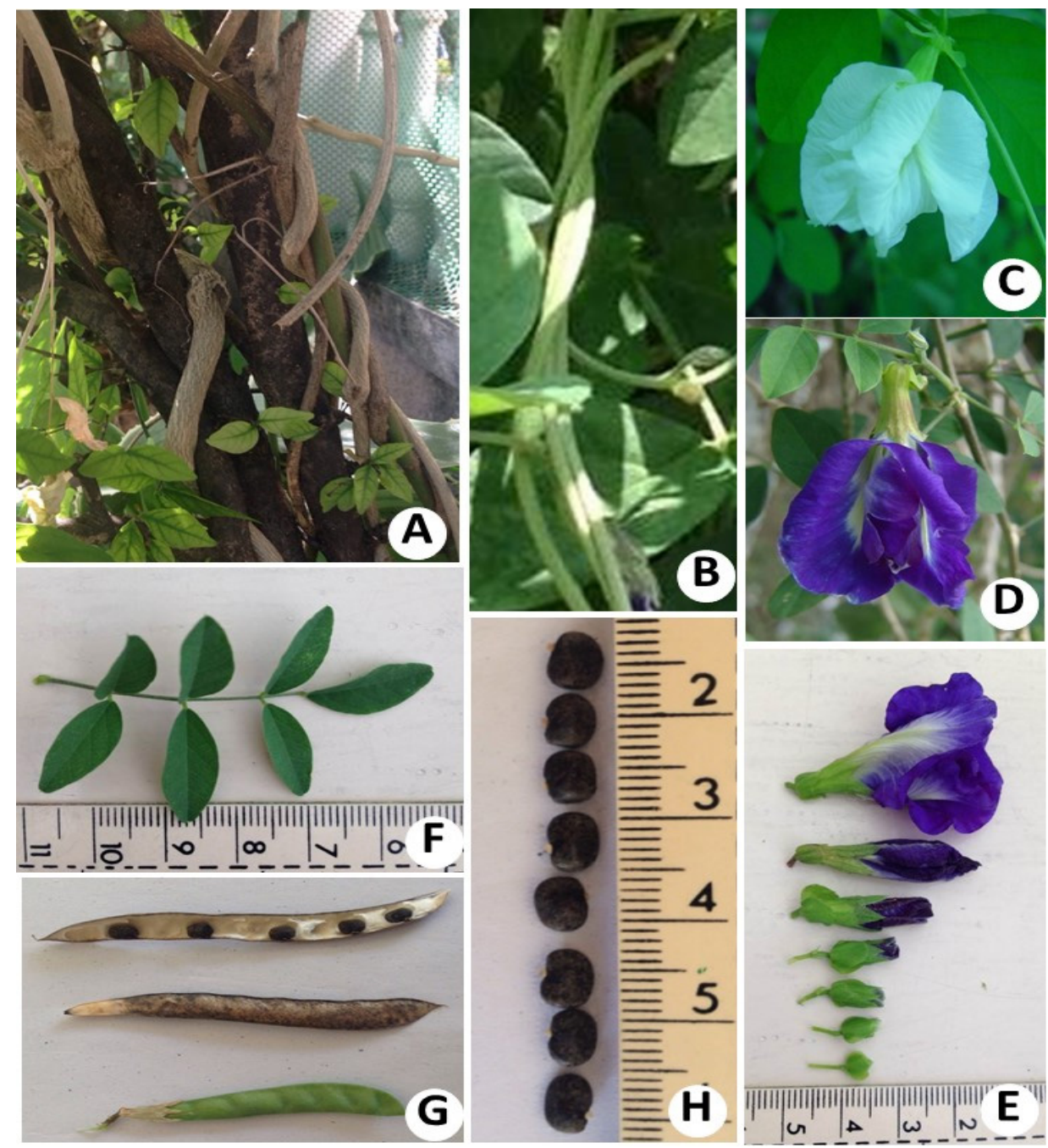

Fig. 1. Clitoria ternatea showing. (a) Twining stems. (b) Twining braches. (c) White flower. (d-e) Blue flowers. (f) Pinnate leaves. (g) Pods. (h) Seeds. 
growing wild and also in gardens, bearing conspicuous blue or white flowers resembling a conch-shell. The root system consists of a fairly stout taproot with few branches and many slender lateral roots. The thick horizontal root, which may grow to more than $2 \mathrm{~m}$ long, bears one to several purplish, glaucous, wiry stems. The leaves are pinnate, petioles $2-2.5 \mathrm{~cm}$ long; stipules $4 \mathrm{~mm}$ long, linear, acute. Leaflets $5-7$, sub coriaceous, $2.5-5$ by $2-3.2$ $\mathrm{cm}$, elliptic-oblong, obtuse or caute; stipules filiform. The flowers are solitary, deep blue to blue, mauve or sometimes white, with an orange center, very short pedicellate and $4-5 \mathrm{~cm}$ long. The pods are flat, linear, beaked, 6-12 cm long, 0.7-1.2 $\mathrm{mm}$ wide and slightly pubescent with up to 10 seeds. The seeds are yellowishbrown or blackish in color and sub-globose or oval in shape, 4.5-7.0 $\mathrm{mm}$ long and 3-4 $\mathrm{mm}$ wide ${ }^{10,12}$.

\section{Phytochemical Substances}

The analysis of $C$. ternatea leaves were reported the amount of ash (8.7\%), moisture (74.5\%), crude fiber $(8.5 \%)$, protein $(14.9 \%)$, and carbohydrate $(0.1 \%)$. Among the various macronutrients estimated in the leave, nitrogen $(2.4 \mathrm{~g})$ was present in the highest quantity, followed by potassium $(1.6 \mathrm{~g})$, calcium $(0.8 \mathrm{~g})$, phosphorus (0.7 g), magnesium (0.6 g) sodium (0.3 g), iron $(6.3 \mathrm{mg})$, zinc $(4.4 \mathrm{mg})$, manganese $(3.2 \mathrm{mg}$ ) and copper (2.2 mg) per $100 \mathrm{~g}^{13}$. Moreover, C. ternatea root was reported the highest amount of carbohydrate (64.1 $\%)$, followed by protein (14.4\%), ash (9.5\%), and crude fiber $(0.7 \%)$. Magnesium $(3.4 \mu \mathrm{g} / \mathrm{ml})$ was present in the highest mineral, followed by zinc $(2.1 \mu \mathrm{g} / \mathrm{ml})$, manganese $(0.5 \mu \mathrm{g} / \mathrm{ml})$, iron $(0.3 \mu \mathrm{g} / \mathrm{ml})$ and copper $(0.2 \mu \mathrm{g} / \mathrm{ml})^{14}$.

The major phytoconstituents found in C. ternatea are the pentacyclic triter penoids such as taraxerol and taraxerone ${ }^{15}$, ternatins ${ }^{16,17}$, alkaloids, flavonoids, saponins, tannins ${ }^{18}$, and anthocyanins ${ }^{19,20}$. In more detail, in ${ }^{16}$ reported three flavonol glycosides from the petals of C. ternatea, their structures were identified using spectroscopy shown as kaempferol 3-O-(2"$O$-alpha-rhamnosyl-6"-O-malonyl)-beta-glucoside, querctin 3-O-(2"-O-alpha-rhamnosyl-6"-O-malonyl)beta-glucoside, and myricetin 3-O-(2", 6"-di-O-alpharhamnosyl)-beta-glucoside. Author in ${ }^{17}$ also identified ternatins structures comprising 15 delphinidin 3-O-(6"$O$-malonyl)-beta-glucoside derivatives substituted at both the 3 '-and 5 '-OH groups with glucose or acylated glucose chains of various length, and which are responsible for blue anthocyanin petal color in $C$. ternatea. In addition, the color of the anthocyanins is widely used as a natural food coloring, can range from deep blue to magenta depending on the $\mathrm{pH}$ of a surrounding ${ }^{19}$.

Author in ${ }^{21}$ evaluated the activities of phytoconstituents such as Varidiflorene: 1a,2,3,5,6,7,7a,7b-octahydro-1,1,4,7-tetramethyl-,[1aR(1aà,7à,7aá,7bà)]- $\left[\mathrm{C}_{15} \mathrm{H}_{24}\right]$ has anti-tumor, antibacterial and anti-inflammatory activities. Homopterocarpin: 6H-benzofuro[3,2-c][1]benzopyran,6a, 11a-dihydro3,9-dimethoxy-,(6aR-cis)- $\left[\mathrm{C}_{17} \mathrm{H}_{16} \mathrm{O}_{4}\right]$ and Procarpin $1 \mathrm{H}$-cycloprop[e] azulene $\left[\mathrm{C}_{17} \mathrm{H}_{14} \mathrm{O}_{5}\right]$ have antimicrobial activities. Isoparvifuran $\left[\mathrm{C}_{16} \mathrm{H}_{14} \mathrm{O}_{3}\right]$, Hexadecanoic acid $\left[\mathrm{C}_{18} \mathrm{H}_{36} \mathrm{O}_{2}\right]$, Myo-Inositol, 4-C-methyl- $\left[\mathrm{C}_{7} \mathrm{H}_{14} \mathrm{O}_{6}\right]$, 1,2,3,5-Cyclohexanetetrol, (1à,2á,3à,5á)- $\quad\left[\mathrm{C}_{6} \mathrm{H}_{12} \mathrm{O}_{4}\right]$, and Propane, 1,1-diethoxy- $\left[\mathrm{C}_{7} \mathrm{H}_{16} \mathrm{O}_{2}\right]$ have antioxidant, antidiabetic, anti-tumor and sedative activities. They were identified from ethanol extract of C. ternatea by using a gas chromatograph-mass spectrograph ${ }^{21}$. Moreover, ${ }^{22}$ identified the major chemical constituents in the methanol extract of flowers were inositol (33.6\%), cyclohexen, 1-methyl-4-(1-methylethylideme) (7.1\%), acetic acid, cyano- (6.5\%) and hirsutene (5.7\%).

\section{Traditional Uses}

C. ternatea is traditionally used for anti-bacterial ${ }^{12,23}$, anti-fungal $^{24}$, anti-helmintic ${ }^{25-27}$, anti-diarrheal ${ }^{28}$, antioxidant ${ }^{29-31}$, anti-hyperlipidemic ${ }^{32}$, anti-pyretic ${ }^{33}$, anti-inflammatory ${ }^{34}$, and anti-diabetic activities ${ }^{35,36}$, immunomodulatory $^{32}$, wound healing property $^{37}$, hepatic ${ }^{9}$, renal ${ }^{21}$, and urogenital diseases ${ }^{38}$.

\section{Neuropharmacological Effects}

C. ternatea is reported to be a good "Medhya" (toning the brain) drug mainly used in the treatment of "Masasika roga" (mental illness). Author in ${ }^{39}$ reported intraperitoneal administration of alcoholic extract of stem, flower, leave and fruit of C. ternatea to rats and mice, has been reported to produce sedation and diminished alertness. Taranalli and Cheeramkuzhy ${ }^{40}$ reported oral treatment with alcoholic extract of aerial 
and root parts of C. ternatea at 300 and $500 \mathrm{mg} / \mathrm{kg}$ in rats in attenuating electroshock-induced amnesia, has been reported to improve memory retention, increase acetylcholine content and acetylcholinesterase activity in the different regions of the brain, viz., cerebral cortex, midbrain, medulla oblongata and cerebellum. Author in ${ }^{41}$ studied the 50 and $100 \mathrm{mg} / \mathrm{kg}$ of C. ternatea aqueous root extract for 30 days in neonatal rat (7 days old) via behavioral tests as follows open field behavior test, passive avoidance test, and spatial learning test. The extract was significantly improved retention and spatial learning performance, indicating the memory enhancing. Author in ${ }^{42}$ also reported the $100 \mathrm{mg} / \mathrm{kg}$ of C. ternatea aqueous root extract for 30 days in neonatal and young adult age groups of rat, significantly increased acetylcholine content in their hippocampus. It may be the neurochemical basis for their improved learning and memory. Author in ${ }^{43}$ investigated the spectrum of activity of the methanolic extract of the aerial parts of C. ternatea on the central nervous system. They studied the effects on the cognitive behavior, anxiety, stress and convulsions induced by pentylenetetrazol and maximum electroshock in mice and rats. They also studied the effects on behavior mediated via dopamine (haloperidolinduced catalepsy), noradrenaline (clonidine-induced hypothermia), serotonin (lithium-induced head twitches) and acetylcholine (sodium nitrite-induced respiratory arrest). The results showed that the $C$. ternatea extract decreased time required to occupy the central platform or transfer latency in the elevated plus maze and increased discrimination index in the object recognition test, indicating nootropic activity. The extract increased occupancy in the open arm of elevated plus maze by $160 \%$ and in the lit box of the light/dark exploration test by $157 \%$, indicating its anxiolytic activity. It decreased the duration of immobility in the tail suspension test, indicating its antidepressant activity. It reduced stress-induced ulcers, indicating its anti-stress activity. It reduced the convulsing action of pentylenetetrazol and maximum electroshock -induced seizures, indicating its anticonvulsant activity. Author $\mathrm{in}^{44}$ reported the ethanolic extract of C. ternatea (100, 200 and $400 \mathrm{mg} / \mathrm{kg}$ ) after 60 minutes oral administration, reduced the marble burying behavior and loco motor activity in mice, indicated that this plant can modulate obsessive compulsive disorder, which is a disabling psychiatric condition. Author in $^{45}$ studied the antianalgesic activity of methanolic extract of $C$. ternatea leaves $(200$ and $400 \mathrm{mg} / \mathrm{kg}$ ) using acetic acid induced writhing test, and studied the anti-depressant activity by using hole cross and open field tests. The results showed this plant inhibited 82.67 and $87.87 \%$ of writhing test and also decreased motor activity and exploratory behavior of mice in the hole cross and open field test in dose dependence.

Author in ${ }^{46}$ evaluated the potential use of standard Ayurvedic formulation name "Vayasthapana Rasayana" as an anti-oxidant to fight age-related problems. This formulation consists of equal parts of Asparagus racemosus, Boerhaavia diffusa, C. ternatea, Centella asiatica, Phyllanthus emblica, Terminalia chebula and Tinospora cordifolia. The other polyherbal formulation name "Rheumatone" using five medicinal plants $C$. ternatea, Sida cordifolia, Cleodendron serratum, Bacopa monnieri and Cardiospermum halicacabum has the enzymatic antioxidant activity. There was a reduction in the levels of super oxide dismutase, catalase, peroxidase and glutathione peroxidase in the liver and kidney of arthritic rats ${ }^{9}$. The commercial product, Perment, a polyherbal Ayurvedic formulation that contains equal parts of $C$. ternatea, Withania somnifera, A. racemosus, and $B$. monniera, is used clinically as mood elevators ${ }^{47}$. The 75 and $150 \mathrm{mg} / \mathrm{kg}$ of Perment predominantly exhibited antidepressant action than anxiolytic activity. Further Perment increased the plasma noradrenaline and serotonin levels in stressed rats but decreased adrenal corticosterone level ${ }^{47}$.

In conclusion, it was suggested that an increase in acetylcholine in the hippocampus may be the neurochemicals basis for improved learning and memory. The other mechanism is a neurogenic growth promoter that will increase in survival, growth and development of the newborn neurons, critical for the repair and restoration of the normal neural circuitry in various diseases. The present article reviews that $C$. ternatea may also be the memory booster or enhancer in any disorders related to loss of learning ability and disorders of memory as in Alzheimer's disease.

\section{Conflict of Interests}

The authors do not have any conflict of interest to declare. 


\section{References}

1. Anand R, Gill KD, Mahdi AA. Therapeutics of Alzheimer's disease: past, present and future. Neuropharmacol. 2014; $76: 27-50$.

2. Hebert LE, Weuve J, Scherr PA, Evans DA. Alzheimer disease in the United States (2010-2050) estimated using the 2010 Census. Neurol. 2013; 80(19):1778-83.

3. Charernboon T, Phanasathit M. Prevalence of neuropsychiatric symptoms in Alzheimer's disease: A cross-sectional descriptive study in Thailand. J Med Assoc Thailand. 2014; 97(5):560-5.

4. Colovic MB, Krstic SZ, Lazarevic-Pasti TD, Bondzic AM, Vasic VM. Acetylcholinesterase inhibitors: Pharmacology and toxicology. Curr Neuropharmacol. 2013; 11(3):31535 .

5. Kumar A, Ekavali AS. A review on alzheimer's disease pathophysiology and its management: an update. Pharmacol Reports. 2015; 67(2):195-203.

6. Bhowmik D, Tiwari P, Tripathi KK, Sampath KP. Traditional Indian memory enhancer herbs and their medicinal importance. Ann Biol Res. 2010; 1(1):41-6.

7. Kumar H, More SV, Han SD, Choi JY, Choi DK. 2012. Promising therapeutics with natural bioactive compounds for improving learning and memory - A review of randomized trials. Molecules. 2012; 17(9):10503-39.

8. Jatwa V, Khirwadkar P, Dashora K. Indian traditional memory enhancing herbs and their medicinal benefits. Indian J Res Pharm Biotechnol. 2014; 2:1030-7.

9. Zingare ML, Zingare PL, Dubey AK, Ansari MS. Clitoria ternatea (Aparajita): A review of the antioxidant, antidiabetic and hepatoprotective potentials. Int J Pharm Biol Sci. 2013; 3:203-13.

10. Mukherjee PK, Kumar V, Kumar NS, Heinrich M. The Ayurvedic medicine Clitoria ternatea - From traditional use to scientific assessment. J Ethnopharmacol. 2008; 120(3):291-301.

11. Subramanian MS, Prathyusha P. Pharmaco-phytochemical characterization of Clitoria ternatea Linn. Int J PharmTech Res. 2011; 3:606-12.

12. Anand SP, Doss A, Nandagopalan V. Antibacterial studies on leaves of Clitoria ternatea linn. - A high potential medicinal plant. Int J App Biol Pharm Technol. 2011; 2(3):453-6.

13. Deshmukh S, Jadhav V. Bromatological and mineral assessment of Clitoria ternatea Linn. Leaves. Int J Pharm Pharm Sci. 2014; 6(3):244-6.
14. Deka M, Medhi AK, Kalita JC. Biochemical estimation of primary metabolites and mineral composition of Clitoria ternatea Linn roots. Bioscan. 2013; 8(2):713-6.

15. Kumar V, Mukherjee K, Kumar S, Mal M, Mukherjee PK. Validation of HPTLC method for the analysis of taraxerol in Clitoria ternatea. Phytochem Anal. 2008; 19(3):244-50.

16. Kazuma K, Noda N, Suzuki M. Malonylated flavonol glycosides from the petals of Clitoria ternatea. Phytochem. 2003; 62(2):229-37.

17. Kazuma K, Kogawa K, Noda N, Kato NSM. Identification of delphinidin 3-O-(6"-O-malonyl)-beta-glucoside3'-O-beta-glucoside, a postulated intermediate in the biosynthesis of ternatin C5 in the blue petals of Clitoria ternatea (butterfly pea). Chem Biodiver. 2004; 1:1762-70.

18. Manalisha D, Chandra KJ. Preliminary phytochemical analysis and acute oral toxicity study of Clitoria ternatea Linn. roots in albino mice. Int Res J Pharm. 2011; 2:13940.

19. Kungsuwan K, Singh K, Phetkao S, Utama-ang N. Effects of $\mathrm{pH}$ and anthocyanin concentration on color and antioxidant activity of Clitoria ternatea extract. Food App Biosci J. 2014; 2:31-46.

20. Chong FC, Gwee XF. Ultrasonic extraction of anthocyanin from Clitoria ternatea flowers using response surface methodology. Nat Prod Res. 2015; 29(15):1485-7. Doi: 10.1080/14786419.2015.1027892

21. Sarumathy K, Dhana Rajan MS, Vijay T, Jayakanthi J. Evaluation of phytoconstituents, nephroprotective and antioxidant activities of Clitoria ternatea. J Appl Pharm Sci. 2011; 1(5):164-72.

22. Neda GD, Rabeta MS, Ong MT. Chemical composition and anti-proliferative properties of flowers of Clitoria ternatea. Int Food Res J. 2013; 20:1229-34.

23. Pahune B, Niranjane K, Danao K, Bodhe M, Rokade V. Antimicrobial activity of Clitoria ternatea $\mathrm{L}$. flower extract and use as a natural indicator in acid base titration. J Natl Prod. 2013; 3:48-51.

24. Neela D, Padma C. Antifungal effect of Clitoria ternatea L. leaf extract on seeds of Pisum sativum L. in relation to the activities of some enzymes. Int J Res Ayu Pharm. 2014; 5:99-101.

25. Nahar K, Rahman MA, Parvin MN, Sarwar S. Evaluation of anthelmintic activity of aqueous leaf extract of Clitoria ternatea Linn. Stamford J Pharm Sci. 2010; 3(1):46-8.

26. Salhan M, Kumar B, Sharma P, Sandhar HK, Gautam M. Comparative anthelmintic activity of aqueous and ethanolic leaf extract of Clitoria ternatea. Int J Drug Develop Res. 2011; 3:62-8. 
27. Sarojini N, Kanti CC, Singh Das MD, Priyanka J, Kumari SU. Anthelmintic activity of Clitoria ternatea leaf extracts. J Pharm Res Opinion. 2012; 2:49-50.

28. Upwar N, Patel R, Waseem N, Mahobia NK. Evaluation of antidiarrhoeal activity of the root of Clitoria ternatea Linn. Int J Pharm Sci Rev Res. 2010; 5(1):131-4.

29. Jayachitra A, Padma PR. Antioxidant potential of Clitoria ternatea leaf extracts in vitro. Int J Pharm Biol Sci. 2012; 3(4):753-63.

30. Madhu, K. Phytochemical screening and antioxidant activity of in vitro growth plants Clitoria ternatea L., using DPPH assay. Asian J Pharm Clin Res. 2013; 6(2):38-42.

31. Phrueksanan W, Yibchok-anun S, Adisakwattana S. Protection of Clitoria ternatea flower petal extract against free radical-induced hemolysis and oxidative damage in canine erythrocytes. Res Vet Sci. 2014; 97(2):358-64.

32. Solanki YB, Jain SM. Anti-hyperlipidemic activity of Clitoria ternatea and Vigna mungo in rats. Pharm Biol. 2010; 48(8):915-23.

33. Murugalakshmi M, Valli G, Mareeswari P, Thangapandian V. Antipyretic and purgative activities of Clitoria ternatea leaves extracts. World J Pharm Pharm Sci. 2013; 3(1):6327.

34. Suganya G, Sampath Kumar P, Dheeba B, Sivakumar R. In vitro antidiabetic, antioxidant and anti-inflammatory activity of Clitoria ternatea L. Int J Pharm Pharm Sci. 2014; 6(7):342-7.

35. Kavitha R, Premalakshmi V. Studies on the synergetic effect of Trichosanthes dioica and Clitoria ternatea leaf extract on the streptozotocin-induced diabetic rats. International J Res Pharm Biomed Sci. 2012; 3(3):1056-64.

36. Talpate KA, Bhosale UA, Zambare MR, Somani R. Antihyperglycemic and antioxidant activity of Clitorea ternatea Linn on streptozotocin-induced diabetic rats. An Int Quart J Res Ayu. 2013; 34(4):433-9.

37. Maity N, Nema NK, Sarkar BK, Mukherjee PK. Standardized Clitoria ternatea leaf extract as hyaluronidase, elastase and matrix-metalloproteinase-1 inhibitor. Indian J Pharmacol. 2012; 44(5):584-7.
38. Uma B, Prabhaka K, Rajendran S. Phytochemical analysis and antimicrobial activity of Clitoria ternatea Linn against extended spectrum beta lactamase producing enteric and urinary pathogens. Asian J Pharm Clin Res. 2009; 2(4):94-6.

39. Kulkarni C, Pattanshetty JR, Amruthraj G. Effect of alcoholic extract of Clitoria ternatea Linn. on central nervous system in rodents. Indian J Exp Biol. 1988; 26(12): 957-60.

40. Taranalli AD, Cheeramkuzhy TC. Influence of Clitoria ternatea memory and central cholinergic activity in rats. Pharm Biol. 2000; 38(1):51-6.

41. Rai KS, Murthy KD, Karanth KS, Rao MS. Clitoria ternatea (Linn) root extract treatment during growth spurt period enhances learning and memory in rats. Indian J Physiol Pharmacol. 2001; 45(3):305-13.

42. Rai KS, Murthy KD, Karanth KS, Nalini K, Rao MS, Srinivasan KK. Clitoria ternatea root extract enhances acetylcholine content in rat hippocampus. Fitoterapia. 2002; 73(7-8):685-9.

43. Jain NN, Ohal CC, Shroff SK, Bhutada RH, Somani RS, Kasture VS, Kasture SB. Clitoria ternatea and the CNS. Pharmacol Biochem Behav. 2003; 75(3):529-36.

44. Shende V, Sahane R, Lawar M, Hamdulay N, Langote H. Evaluation of anti-compulsie effect of ethanolic extract on Clitoria ternatea in mice. Asian J Pharm Clin Res. 2012; 5:120-3.

45. Sarwar S, Rahman MdR, Nahar K, Rahman MA. Analgesic and neuropharmacological actiivties of methanolic leaf extract of Clitoria ternatea Linn. J Pharm Phytochem. 2014; 2(5):110-4.

46. Mukherjee S, Pawar N, Kulkarni O, Nagarkar B, Thopte S, Bhujbal A, Pawar P. Evaluation of free-radical quenching properties of standard Ayurvedic formulation Vayasthapana Rasayana. BMC Complement Altern Med. $2011 ; 11: 38$.

47. Ramanathan M, Balaji B, Justin A. Behavioural and neurochemical evaluation of Perment an herbal formulation in chronic unpredictable mild stress induced depressive model. Indian J Exp Biol. 2011; 49(4):269-75. 